\title{
ENTREPRENEUR
}

Jurnal Bisnis Manajemen Dan Kewirausahaan

Program Studi Manajemen Fakultas Ekonomika dan Bisnis Universitas Majalengka

Published every January and July e-ISSN : (Proses), p-ISSN: 2723-1941

Available online https://ejournal.unma.ac.id/index.php/entrepreneur

\section{Pengaruh Iklan Dan Citra Merek \\ Terhadap Kepuasan Konsumen \\ (Studi Pada Konsumen sepeda Motor Honda PT Helmi Hendra Motor \\ Maja Majalengka)}

Pipih Sopiyan

Fakultas Ekonomika dan Bisnis Universitas Majalengka

Emaiil : pipihoke@gmal.com

\begin{tabular}{|c|}
\hline ABSTRACTS \\
\hline $\begin{array}{l}\text { This research is motivated by the problem of companies that still use print media to advertise } \\
\text { goods, while currently there is digital technology that is more efficient for advertising and } \\
\text { brand images. This study aims to determine the effect of advertising, brand image on } \\
\text { consumer satisfaction of Honda motorbikes at PT Helmi Hendra Motor Maja either partially } \\
\text { or simultaneously, using descriptive and verifiative analysis approaches so as to increase } \\
\text { product sales and revenue. Testing instruments using validity and reliability tests with a litert } \\
\text { scale. The analytical tool used in this research is the Classical Assumption test, the } \\
\text { Coefficient of Determination and Multiple Linear Regression. While testing the hypothesis } \\
\text { using the t test for partial and test for silmutan. It can be seen that advertising is in the good } \\
\text { category, brand image is in the good category, and customer satisfaction is in the high } \\
\text { category. Partially that advertising has a significant effect on customer satisfaction, brand } \\
\text { image has a significant effect on customer satisfaction. Simultaneously, advertising and } \\
\text { brand image have a significant effect on customer satisfaction. }\end{array}$ \\
\hline Kata Kunci: Advertising;Brand Image; Customer Satisfaction \\
\hline
\end{tabular}




\section{ENTREAPRENEUR \\ Jurnal Bisnis Manajemen Dan Kewirausahaan \\ Program Studi Manajemen Fakultas Ekonomika dan Bisnis Universitas Majalengka \\ Published every January and July e-ISSN : (Proses), p-ISSN: 2723-1941 \\ Available online https://ejournal.unma.ac.id/index.php/entrepreneur}

\section{PENDAHULUAN}

Di era globalisasi ini manajemen pemasaran merupakan suatu disiplin ilmu yang dimiliki arti sangat penting dalam dunia usaha karena semakin majunya teknologi dalam berbagai bidang menurut setiap orang atau lembaga (perusahaan) untuk selalu berkompetensi dalam rangka mencapai suatu tujuan yang telah diitetapkan yaitu memperoleh keuntungan yang optimal dengan pengeluaran yang seminimal mungkin.

Kepuasan adalah mencerminkan penilaian komparatif seseorang yang merupakan hasil dari kinerja (atau hasil) yang dirasakan dari produk dalam hubungan dengan harapan. Jika kinerja jauh dibawah harapan, pelanggan tidak puas dan kecewa. Jika kinerja sesuai dengan harapn, pelanggan puas. Jika kinerja melampaui harapa, pelanggan sangat puas dan senang menurut Kotler dan Keller (2007:31).

Berdasarkan uraian diatas kepuasan konsumen dipengaruhi oleh berbagai faktor, salah satu hal yang mempengaruhi seseorang melakukan pembelian yaitu iklan dan citra merek. Pada era modern seperti sekarang ini iklan dan citra merek sangatlah penting. Dengan adanya iklan konsumen bisa mencari referensi dan optini-optini tentang suatu produk yang dia inginkan dengan mudah.karena pada saat ini konsumen selalu mencari referensi dan lebih mempercai optini-optini dalam komunitas tentang produk.

Iklan yang artinya mengiring orangorang kepada gagasan. Iklan adalah informasi yang isinya membujuk khayalan banyak atau orang banyak supaya tertarik kepada barang atau jasa yang ditawarkan. Iklan menurut Tjiptono (2008:52) dapat dimanfaatkan secara efektif untuk membangun citra jangka panjang produk maupan perusahaan dan dapat memincu pembelian. Baik sebuah merek adalah ketika menjadi iklan di kalangan konsumen. Keberhasilan inovasi perusahaan dibidang pemasaran ini dapat menghidupkan merek dan menjadi pembicaraan.

Percapaian baik sebuah merek adalah ketika menjadi iklan dikalangan konsumen. Keberhasilan inovasi perusahaan di bidang pemasaran ini dapat menghidupkan merek dan menjadi pembicaraan terus menerus. Tentunya memberikan keuntungan bagi perusahaan. Citra merek merupakan hasil penilaian persepsi konsumen terhadap suatu merek baik itu positif atau negatif. Sedangkan menurut Setiadi (2007:120) citra merek merupakan representasi dari keseluruhan persepsi terhadap merek dan dibentuk dari informasi dan pengalaman masa lalu terhadap merek tersebut dan preferensi terhadap suatu merek. Konsumen yang memiliki citra yang positif terhadap suatu merek, akan mungkin lebih memungkinkan melakukan pembelian.

Helmi Hendra Motor atau lebih dikenal Dealer Motor Honda merupakan perusahaan yang ada di maja, memiliki beberapa jenis berbagai produk merek Honda lainya.Semakin tinggi nya jumlah motor honda, maka semakin tinggi pula kebutuhan akan motor honda.

Tujuan periklanan adalah membujuk konsumen untuk melakukan sesuatu, biasanya untuk membeli sebuah produk. Agar priklanan dapat menarik dan berkomunikasi dengan kelayaknya dalam acara tertentu sehingga membuahkan hasil yang diinginkan, iklan yang dibuat semenarik mungkin yang bisa menimbulkan ketertarikan akan citra merek yang dibawa oleh iklan dengan demikian ada motivasi 


\section{ENTREPRENEUR}

\section{Jurnal Bisnis Manajemen Dan Kewirausahaan}

Program Studi Manajemen Fakultas Ekonomika dan Bisnis Universitas Majalengka

Published every June and December e-ISSN : (Proses), p-ISSN: 2723-1941

Available online https://ejournal.unma.ac.id/index.php/entrepreneur

dan keinginan untuk melakukuan pembelian dan mencoba untuk menggunkan produk. Citra yang dibentuk harus jelas dan memiliki keunggulan bila dibandingkan dengan pesaingnya.

Citra merek merupakan suatu perusahaan berhasil mencitakan citra merek yang positif dan kuat maka hasilnya akan dirasakan dalam jangka panjang terlebih bila selalu mampu memeliharanya yaitu dengan selalu konsisten memberikan, memenuhi janji yang melakat pada citra yang sngaja dibentuk tersebut.

Perusahaan tersebut bergerak dalam bidang penjualan suku cadang atau sparepart khusus untuk sepeda motor Honda. Sparepart yang disediakan oleh perusahaan antara lain meliputi kelompok mesin generetor, floor panel, headlight dan lain sebagainya. Sparepart tersebut tersedia untuk berbagai macam jenis sepeda motor Honda, diantaranya adalah Honda Beat, Tiger, Vario serta beberapa jenis lainnya. Itu merupakan beberapa produk yang dikeluarkan perusahaan honda. Dan yang menjadi produk unggulannya saat ini adalah produk honda Beat yang saat ini laku terjual ke pasaran.

Dalam proses penjualannya perusahaan masih terkendala beberapa hal, antara lain perusahaan kesulitan dalam melayani kebutuhan transaksi konsumen dari luar kota karena proses pembelian dan pembayaran pada saat ini dilakukan hanya di tempat penjualan. Perusahaan membutuhkan sarana yang dapat mempermudah dalam mengelola pembayaran konsumen. Perusahaan kesulitan dalam memberikan informasi yang lebih lengkap mengenai produk yang dijualnya karena untuk menjelaskan mengenai sparepart satu jenis motor saja dibutuhkan katalog yang tidak sedikit, hal itu sama artinya menambah biaya operasional. Untuk mengatasi permasalahan yang terjadi saat ini yaitu dengan pemasangan iklan dan lebih mengurangi penggunaan media katalog karena hanya menghabiskan jasa prinan, dan sebagainya. Untuk itu perusahaan harus mengenal literasi pemasaran saat ini. Di era abad ke 21 bidang perusahaan harus lebih mengedepankan sistem teknologi sebagai alat komunikasi dengan pihak konsumen, agar tidak tertinggal dengan perusahaanperusahaan besar lainnya.

Untuk memecahkan masalah yang terjadi, maka diperlukan suatu sistem yang dapat menangani permasalahan tersebut, yaitu dengan membangun sistem perdagangan secara online. Penggunaan ini dapat dijadikan sebagai solusi untuk membantu perusahaan dalam mengembangkan usaha dan menghadapi persaingan bisnisnya dapat meningkatkan efisiensi dan efektifitas dalam berbisnis, dapat meningkatkan kualitas informasi mengenai produk yang ditawarkan serta mengurangi biaya operasional sehingga biaya produksi dan pemasaran dapat ditekan sedemikian rupa tanpa mengurangi kualitas yang ada. Aktivitas perdagangan ini melalui mediainternet 


\section{ENTREPRENEUR}

Jurnal Bisnis Manajemen Dan Kewirausahaan

Program Studi Manajemen Fakultas Ekonomika dan Bisnis Universitas Majalengka

Published every January and July e-ISSN : (Proses), p-ISSN: 2723-1941

Available online https://ejournal.unma.ac.id/index.php/entrepreneur

memiliki banyak manfaat. Adapun manfaat yang dapat diambil dari penerapan baik dari pihak perusahaan ataupun pihak konsumen antara lain, perusahaan dapat mengembangkan bisnisnya, pelayanan penjualan tidak hanya dilakukan dikota tempat penjualan berada tetapi dapat melayani kebutuhan transaksi konsumen yang berada diluar kota, hal ini sama artinya dengan meningkatkan keuntungan perusahaan. Konsumen dapat memperoleh kenyamanan pembayaran karena pembayaran dapat dilakukan dimanapun. Perusahaan dapat memberikan informasi yang lebih lengkap mengenai sparepart (selanjutnya disebut juga produk) yang dijual tanpa harus mencetak katalog secara berulang-ulang.

Perkembangan dunia periklanan pada saat ini yang semakin pesat dan didukung oleh pertumbuhan media cetak maupun jumlah stasiun televisi (media elektronik) yang terus meningkat, membuat perusahaan harus selektif dalam membuat iklan untuk mendukung penjualannya. Strategi pemasaran dan promosi yang tepat dan efisien diperlukan agar efektivitas komunikasi iklan dapat dicapai. Selain itu, dukungan dari citra merek yang selama ini dibangun dan dijaga dengan baik oleh Honda, dapat membantu Honda untuk tetap bertahan di tengah ketatnya persaingan industri sepeda motor di Indonesia.

Berdasarkan uraian di atas perlu dikaji lebih dalam mengenai iklan dan citra merek yang mempengaruhi keputusan pembelian, supaya mengetahui pendapat konsumen tentang suatu produk yang dipasarkan dan mengenalan suatu merek baru maupun merek yang sudah ada agar orang lain mengenali/mengingat kembali bahwa suatu merek marupakan bagian dari kategori produk tertentu yang dapat memperngaruhi konsumen dalam keputusan pembelian.

\section{KAJIAN PUSTAKA, KERANGKA PEMIKIRAN, DAN HOPOTESIS Bauran Pemasaran}

Menurut Miller dan Layton dikutif oleh Tjiptono (2004:2) adalah system total aktivitas bisnis yang dirancang untuk merencanakan, menetapkan harga, mempromosikan dan mendistribusikan produk, jasa dan gagasan yang mampu memuaskan keinginan pasar sasaran dalam mencapai tujuan organisasional.

Menurut Philip Kolter yang dialih bahasakan oleh Benyamin Molan (2007:23) bahwa : ada 7 (tujuh) komponen P (Product, Price, Place, Promotion, People, Process, dan Physical Evidence) dalam bauran pemasaran untuk mempengaruhi saluran perdagangan dan penjualan konsumen akhir.

1. Product (The Services) / Produk atau Jasa

Produk (product) adalah mengelola unsur produk termasuk perncanaan dan pengembangan produk atau jasa yang ada dengan menambah dan mengambil tindakan yang lain yang mempengaruhi bermacam-macam produk atau jasa.

2. Harga (Price)

Harga (price) adalah suatu sistem manajemen perusahaan yang akan menunjukan harga dasar yang tepat bagi produk atau jasa dan harus menentukan strategi yang menyangkut potongan harga, pembayaran ongkos angkut dan berbagai variabel yang bersangkutan.

3. Lokasi Usaha (Place)

Memilih lokasi dan tempat dengan pelanggan perlu untuk mempertahankan daya saing, selain faktor kedekatan dengan pelanggan, faktor kenyamanan 


\section{ENTREPRENEUR}

\section{Jurnal Bisnis Manajemen Dan Kewirausahaan}

Program Studi Manajemen Fakultas Ekonomika dan Bisnis Universitas Majalengka

Published every June and December e-ISSN : (Proses), p-ISSN: 2723-1941

Available online https://ejournal.unma.ac.id/index.php/entrepreneur

juga hendak nya diperhatikan dan bagaimana cara menyampaikan kepada konsumen.

4. Strategi Promosi (Promotion)

Promosi adalah memberikan informasi dan memperkenalkan produk kepada pembeli dengan harapan mereka dan secara sukarela membeli produk. Yang perlu diperhatikan dalam promosi adalah memilih bauran promosi yang terdiri : periklanan, personal selling, public relations dan promosi penjualan.

5. Sumber Daya Manusia / People (SDM) Dalam hubungan dengan pemasaran jasa, maka people yang berfungsi sebagi service prodiver sangat mempengaruhi kualitas jasa yang diberikan. Keputusan dalam people ini berarti sehubungan dengan seleksi., training dan motivasi, dan manajemen sumberdaya manusia untuk mecapai kualitas yang terbaik maka pegawai haus dilatih untuk menyadari pentingnya.

6. Proses atau Aktivitas Bisnis (Process)

Proses merupakan faktor penting bagi konsumen, umumnya dari prosedur, jadwal pekerjaan, mekanisme dan aktivitas lainnya, dimana dalam jasa dapat dihasilkan dan disampaikan kepada konsumen

7. Bukti Fisik Perusahaan (Physical Evidence)

Buidling merupakan bagian dari bukti fisik, karakteristik yang menjadi persyaratan yang menilai tambah bagi konsumen dalam peusahaan jasa yang memiliki katakter. Perhatian terhadap interior, perlengkapan bangunan, termasuk lightning system, dan tata ruang yang lapang menjadi perhatian penting dan dapat mempengaruhi mood pengunjung.
Iklan

Menurut Suhandang (2005:13), iklan adalah segala bentuk penyajian dan promosi ide, barang atau jasa secara non-personal oleh suatu sponsor tertentu yang memerlukan pembayaran. periklanaan adalah suatu proses komunikasi massa yang melibatkan sponsor tertentu, yakni si pemasang iklan (pengiklan), yang membayar jasa sebuah media masa atas penyiaran iklan.

Menurut Tjiptono (2008:52) iklan dapat dimanfaatkan secara efektf untuk membangun citra jangka panjang produk maupun perusahaan dapat memicu pembelian.

Iklan didefinisikan (Sulaksana 2007), semua bentuk presentasi non personal yang mempromosikan gagasan, barang atau jasa yang dibiayai pihak sponsor tertentu. Periklanan adalah komunikasi komersil dan non personal tentang sebuah organisasi dan produk-produknya yang ditransmisikan ke suatu klayak target melalui media bersifat missal

\section{Indikator Iklan}

Menurut Tjiptono (2012:23) Iklan sangat penting memiliki fungsi komunikasi yang kritis, yaitu :

1. Menginformasikan

2. Membujuk

3. Mengingatkan

4. Memberikan Nilai Tambahan

5. Mendukung Usaha Promosi Lainnya 


\section{ENTREPRENEUR}

Jurnal Bisnis Manajemen Dan Kewirausahaan

Program Studi Manajemen Fakultas Ekonomika dan Bisnis Universitas Majalengka

Published every January and July e-ISSN : (Proses), p-ISSN: 2723-1941

Available online https://ejournal.unma.ac.id/index.php/entrepreneur

\section{Citra Merek}

Menurut Kotler (2009:208), citra merek adalah seperangkat keyakinan ide dan kesan yang terbentuk oleh seseorang terhadap suatu objek. Citra merek sendiri adalah suatu gambaran, penyerupaan kesan utama atau garis besar bahkan bayangan yang dimiliki oleh seseorang tentang sesuatu. Oleh karna itu citra merek dapat dipertahankan.

Menurut Setiadi (2007:120), citra merek merupakan representasi dari keseluruhan persepsi terhadap merek tersebut. Citra terhadap merek berhubungan dengan sikap yang berupa keinginan dan preferensi terhadap suatu merek. Komponen yang memiliki citra merek yang poitif terhadap suatu merek, akan lebih memungkinkan untuk melakukan pembelian.

\section{Kepuasan Konsumen}

Kepuasan adalah tingkat perasaan seseorang setelah membandingkan kinerja atau hasil yang dirasakan dengan harapannya. J. Supranto (2006:233) mengemukakan bahwa kepuasan konsumen terjadi karena perusahaan memfokuskan perusahaan pada pelayanan dan kualitas yang diberikan. Kepuasan konsumen memberi keuntungan yang diantaranya adalah bentuk kesetiaan konsumen dan citra perusahaan. Dalam memenangkan persaingan ini maka perusahaan lurus berorientasi kepada penemuan dan memuaskan kebutuhan konsumen. Konsumen dapat memilih dari banyaknya pilihan yang ditawarkan oleh perusahaan. Dalam hal ini, jika perusahaan gagal memberikan kualitas yang dapat menerima maka perusahaan tersebut akan kehilangan konsumen yang akan beralih kepada pesaingnya.

Menurut Kotler dan Keller (2007:31)

Keputusan adalah mencerminkan penilaian komparatif seseorang yang merupakan hasil dari kinerja (atau hasil) yang dirasakan dari produk dalam hubungan dengan harapan. Jika kinerja jauh dibawah harapan, pelanggan tidak puas dan kecewa. Jika kinerja sesuai dengan harapn, pelanggan puas. Jika kinerja melampaui harapa, pelanggan sangat puas dan senang.

\section{Indikator Kepuasan Konsumen}

Menurut Rangkuti

(2004:04)

langkah-langkah dalam proses kepuasan konsumen ini adalah :

1. Menerima atas keluhan konsumen.

2. Tanggapan atas keluhan konsumen.

3. Memberikan informasi dengan baik terhadap sesuatu yang dibutuhkan konsumen.

4. Tetap setia.

5. Memberi perhatian lebih.

6. Konsumen merasa aman dan nyaman selama berurusan dengan perusahaam tersebut.

7. Memberikan saran untuk keluhan konsumen.

\section{Kerangka Pemikiran}

Kepuasan konsumen menjadi faktor yang penting dalam penentu eksistensi atau perusahaan. Suatu perusahaan dalam terus eksis jika rangsangan konsumen dalam memutuskan pembelian produk dari suatu pasar mendapatkan respon yang positif dari pasar itu sendiri.

Menurut Swastha dan Handoko (2008:110), kepuasan konsumen merupakan proses dalam pembelian yang nyata apakah membeli atau tidak. F dari faktor yang mempengaruhi konsumen dalam melakukan 


\section{ENTREPRENEUR}

\section{Jurnal Bisnis Manajemen Dan Kewirausahaan}

Program Studi Manajemen Fakultas Ekonomika dan Bisnis Universitas Majalengka

Published every June and December e-ISSN : (Proses), p-ISSN: 2723-1941

Available online https://ejournal.unma.ac.id/index.php/entrepreneur

pembelian suatu produk atau jasa, biasanya

konsumen selalu mempertimbangkan kualitas, harga, dan produ yang sudah dikenal masyarakat.

Menurut Rangkuti (2004:04)

langkah-langkah dalam proses kepuasan konsumen ini adalah :

1. Menerima atas keluhan konsumen.

2. Tanggapan atas keluhan konsumen.

3. Memberikan informasi dengan baik terhadap sesuatu yang dibutuhkan konsumen.

4. Tetap setia.

5. Memberi perhatian lebih.

6. Konsumen merasa aman dan nyaman selama berurusan dengan perusahaam tersebut.

7. Memberikan saran untuk keluhan konsumen.

Proses penukaran merupakan unsur utama dari perilaku konsumen. Penukaran terjadi antara konsumen dengan perusahaan, disamping itu juga terjadi antara perusahaan pada situasi pembelian industrial dan pertukaran yang terjadi antara konsumen itu sendiri.

Kepuasan konsumen dipengaruhi oleh berbagia faktor, salah satu hal yang mempengaruhi seseorang melakukan pembelian yaitu iklan dan citra merek. Saat ini konsumen selalu mencari referensi dan mempercayai opini-opini tentang suatu produk melalui pasar.

Menurut Suhandang (2005:13), iklan adalah segala bentuk penyajian dan promosi ide, barang atau jasa secara non-personal oleh suatu sponsor tertentu yang memerlukan pembayaran. periklanaan adalah suatu proses komunikasi massa yang melibatkan sponsor tertentu, yakni si pemasang iklan (pengiklan), yang membayar jasa sebuah media masa atas penyiaran iklan.
Menurut Tjiptono (2012:23) Iklan sangat penting memiliki fungsi komunikasi yang kritis, yaitu :

1. Menginformasikan

2. Membujuk

3. Mengingatkan

4. Memberikan Nilai Tambahan

5. Mendukung Usaha Promosi Lainnya.

Komponen yang paling penting didalam suatu iklan adalah pesan yang akan disampaikan oleh iklan tersebut. Iklan yang selalu kita lihat di telivisi atau yang disampaikan di radio dan iklan-iklan yang kita lihat di media cetak merupakan suatu sumber entertaiment, motivasi, fantazy, seperti halnya suatu cara untuk informasi dari suut padang pemasar, pesan iklan adalah suatu cara untuk mengatakan kepada konsumen bagaimana suatu produk atau jasa bisa memecahkan/mengatasi masalah atau menolong dalam dan mencapai suatu tujuan. Aspek yang paling penting menarik dari suatu iklan adalah dari sisi kreatifitasnya. Starategi kreatifitas inilah yang menentukan pesan iklan apa yang akan dikomunikasikan.

Menurut Kolter (2009:208), citra merek adalah seperangkat keyakinan ide dan kesan yang terbentuk oleh seseorang terhadap suatu objek. Citra merek sendiri adalah suatu gambaran, penyerupaan kesan utama atau garis besar bahkan bayangan yang dimiliki oleh seseorang tentang sesuatu. Oleh karna itu citra merek dapat dipertahankan.

Ukuran yang menjadi pertimbangan konsumen dalam memilih atau menilain citra mmerek adalah merek harus memilki kesan positif dibandingnya, reputasi tinggi, dan keunggulan mudaha dikenali. Menurut Kotler \& Keller (2009:359) bahwa pengukur 


\section{ENTTREPRENEUR \\ Jurnal Bisnis Manajemen Dan Kewirausahaan \\ Program Studi Manajemen Fakultas Ekonomika dan Bisnis Universitas Majalengka \\ Published every January and July e-ISSN : (Proses), p-ISSN: 2723-1941 \\ Available online https://ejournal.unma.ac.id/index.php/entrepreneur}

citra merek dapat dilkukan berdasarkan pada aspek sebuah merek, yaitu :

1. Kekuatan asosiasi merek (strength of brand association)

Dalam hal ini adalah keunggulan yang dimiliki oleh merek yang bersifat fisik dan tidak ditemukan pada merek lainya. Keunggulan merek ini mengacu pada atribu-atribut fisik atas merek tersebut sehingga bisa dianggap sebagai sebuah kelebihan dibandingkan dengan merek lainnya. Yang termasuk pasa sekelompok kekuatan (strength) adalah keberfungsian sama fasilitas produk, penampilan fisik, harga produk, maupun penampilan fasilitas pendukung dari produk tersebut dan memiliki cakupan pasar yang luas.

2. Keunikan asosiasi merek (uniqueness of brand association )

Kemampuan untuk membedakan sebuah merek dianatara merek lainnya. Kesan ini muncul dari atribut produk tersebut yang menjadi bahan pembeda atau diferensiasi dengan produk-produk lainya. Yang termasuk dalam kelompok unik ini adalah variasi penampilan atau nama dari sebuah merek yang mudah diingat dan diucapkan, dan fisik produk itu sendiri.

3. Keunggulan asosiasi merek (favourability of brand association)

Yang termasuk dalam kelompok favorable ini antara lain, kemudahan merek produk diucapkan serta kemampuan merek untuk tetap diingat oleh pelanggan yang membuat produk terkenal dan menjadi favorit di masyarakat maupun kesesuaian antara kesan merek di benak pelanggan dengan citra yang diinginkan perusahaan atas merek yang

bersangkutan.

Dari pendapat diatas dapat disimpulkan bahwa citra merek merupakan suatu gambaran, penyerupaan kesan utama atau garis besar bahkan bayangan yang dimiliki oleh seseorang dalam mengingat merek.

\section{Hipotesis}

Pada penelitian ini penulis melihat pengaruh iklan dan citra merek terhadap kepuasan konsumen sepeda motor Honda. Berdasarkan pada latar belakang, perumusan masalah, tujuan penelitian serta uraian di atas, maka didapatkan beberapa hipotesis yaitu :

$\mathrm{H}_{1}$ : Terdapat pengaruh antara iklan terhadap kepuasan konsumen.

$\mathrm{H}_{2}$ : Terdapat pengaruh antara citra merek terhadap keputasan konsumen.

$\mathrm{H}_{3}$ : Terdapat pengaruh antara iklan dan citra merek terhadap kepuasan konsumen.

\section{METODE PENELITIAN}

Metode penelitian melalui pendekatan deskriptif verifikatif dan jenis penelitian adalah survey. Populasi dalam penelitian ini adalah konsumen sepda motor Honda PT Helmi Hendra Motor Talaga Majalengka. Adapun sampel dalam penelitian ini adalah 100 orang. Data diperoleh dengan distribusi kuesioner dengan menggunakan skala likert poin 5. analisis yang digunakan dalam penelitian ini adalah metode analisis regresi. Dengan menggunakan SPSS : 


\section{ENTREPRENEUR}

Jurnal Bisnis Manajemen Dan Kewirausahaan

Program Studi Manajemen Fakultas Ekonomika dan Bisnis Universitas Majalengka

Published every June and December e-ISSN : (Proses), p-ISSN: 2723-1941

Available online https://ejournal.unma.ac.id/index.php/entrepreneur

Tabel 1. Operasionalisasi Variabel

\begin{tabular}{|c|c|c|}
\hline Varibel & Definisi Operasional Variabel & Indikator \\
\hline \multirow{5}{*}{ Iklan (XI) } & \multirow{5}{*}{$\begin{array}{l}\text { Merupakan salah satu } \\
\text { bentuk promosi yang paling } \\
\text { banyak digunakan } \\
\text { perusahaan dalam } \\
\text { mempromosikan produknya }\end{array}$} & 1. Menginformasikan \\
\hline & & 2. Membujuk \\
\hline & & 3. Mengingatkan \\
\hline & & $\begin{array}{l}\text { 4. Memberikan } \\
\text { tambahan }\end{array}$ \\
\hline & & 5. Mendukung usaha promosi \\
\hline \multirow[t]{3}{*}{$\begin{array}{l}\text { Citra Merek } \\
\text { (X2) }\end{array}$} & \multirow{3}{*}{$\begin{array}{l}\text { Kesan positif suatu merek } \\
\text { yang menyebaban merek } \\
\text { tersebut mudah dikenal oleh } \\
\text { konsumen. }\end{array}$} & $\begin{array}{l}\text { 1. Kekuatan asosiasi merek } \\
\text { (srength of } \\
\text { association) }\end{array}$ \\
\hline & & $\begin{array}{l}\text { 2. Keunikan assosiasi merek } \\
\text { (uniques of } \\
\text { association) }\end{array}$ \\
\hline & & $\begin{array}{l}\text { 3. Keunggulan assosiasi } \\
\text { merek (favourability of } \\
\text { barand association) }\end{array}$ \\
\hline \multirow[t]{5}{*}{$\begin{array}{c}\text { Kepuasan } \\
\text { Konsumen }\end{array}$} & \multirow{5}{*}{$\begin{array}{l}\text { Proses ketika seseorang } \\
\text { konsumen memutuskan } \\
\text { akan membeli atau tidaknya } \\
\text { suatu produk setelah melalui } \\
\text { tahap-tahap pertimbangan } \\
\text { dan penyelesaian masalah } \\
\text { ketika membeli sebuah } \\
\text { produk }\end{array}$} & $\begin{array}{l}\text { 1. Menerima atas keluhan } \\
\text { pelanggan }\end{array}$ \\
\hline & & $\begin{array}{l}\text { 2. Tanggapan atas keluhan } \\
\text { konsumen }\end{array}$ \\
\hline & & $\begin{array}{l}\text { 3. Memberikan } \\
\text { dengan baik terhadap } \\
\text { sesuatu yang dibutuhkan } \\
\text { konsumen. }\end{array}$ \\
\hline & & 4. Tetap setia \\
\hline & & 5. Memberi perhatian lebih \\
\hline
\end{tabular}

\section{HASIL DAN PEMBAHASAN}

Hasil Penelitian

Pengujian Instrumen Penelitian

\section{Validitas}

Uji validitas dilakukan untuk menguji kesesuaian instrumen penelitian (item pertanyaan atau pernyataan) dengan konstruk yang akan diukur. Adapun kriteria yang digunakan untuk menilai validitas dari masing-masing pernyataan adalah $r_{\text {hitung }}>$ $\mathbf{r}_{\text {tabel. }}$
Berdasarkan hasil uji validitas data, semua item pertanyaan kuesioner dari masing-masing variabel dalam penelitian ini memiliki koefisien korelasi $\left(\mathrm{r}_{\text {hitung }}\right)$ yang lebih besar dari nilai $r_{\text {tabel }}=0,196$, sehingga kuesioner terbukti valid dan dapat digunakan sebagai alat pengumpulan data. Perhitungan uji validitas dalam penelitian ini menggunakan SPSS 21 dan hasil uji validitas untuk masing-masing variabel dijelaskan dalam tabel 2. 


\section{ENTREPRENEUR}

\section{Jurnal Bisnis Manajemen Dan Kewirausahaan}

\section{Program Studi Manajemen Fakultas Ekonomika dan Bisnis Universitas Majalengka}

Published every January and July e-ISSN : (Proses), p-ISSN: 2723-1941

Available online https://ejournal.unma.ac.id/index.php/entrepreneur

Tabel 2. Hasil Uji Validitas

\begin{tabular}{|c|c|c|c|c|}
\hline Variabel & $\begin{array}{c}\text { Item } \\
\text { Pernyataan }\end{array}$ & $\mathbf{r}_{\text {hitung }}$ & $\mathbf{r}_{\text {tabel }}(\alpha=5 \%)$ & Keterangan \\
\hline \multirow[t]{5}{*}{ Iklan (X1) } & $\mathrm{P} 1$ & 0,650 & \multirow{5}{*}{0,196} & \multirow{5}{*}{ Valid } \\
\hline & $\mathrm{P} 2$ & 0,526 & & \\
\hline & P3 & 0,700 & & \\
\hline & $\mathrm{P} 4$ & 0,646 & & \\
\hline & P5 & 0,696 & & \\
\hline \multirow{5}{*}{$\begin{array}{l}\text { Citra Merek } \\
\text { (X2) }\end{array}$} & P1 & 0,607 & \multirow{5}{*}{0,196} & \multirow{5}{*}{ Valid } \\
\hline & $\mathrm{P} 2$ & 0,466 & & \\
\hline & P3 & 0,670 & & \\
\hline & P4 & 0,549 & & \\
\hline & P5 & 0,623 & & \\
\hline \multirow{7}{*}{$\begin{array}{c}\text { Kepuasan } \\
\text { Konsumen (Y) }\end{array}$} & P1 & 0,738 & \multirow{7}{*}{0,196} & \multirow{7}{*}{ Valid } \\
\hline & P2 & 0,770 & & \\
\hline & P3 & 0,676 & & \\
\hline & P4 & 0,576 & & \\
\hline & P5 & 0,601 & & \\
\hline & P6 & 0,663 & & \\
\hline & P7 & 0,665 & & \\
\hline
\end{tabular}

\section{Uji Reliabilitas}

Uji reliabilitas dilakukan untuk menguji konsistensi instrumen penelitian. Alat uji yang biasa dan populer digunakan adalah uji internal (internal consistency) dengan menggunakan koefisien cronbach alpha.Tingkat koefisien yang disarankan adalah 0,7 (Hair et al., 1998) atau 0,6 (Nunnaly, 1978). Sekaran (2003) mengklasifikasikan tingkat koefisien reliabilitas menjadi tiga: koefisien cronbach alpha kurang dari 0,6 menandakan reliabilitas yang kurang baik, cronbach alpha 0,6 sampai 0,8 menandakan tingkat reliabilitas yang dapat diterima dan cronbach alpha lebih dari 0.8 menandakan reliabilitas yang baik.
Angka cronbach alpha variabel iklan (X1), citra merek (X2), dan kepuasan konsumen (Y) masing-masing lebih besar dari cut of value $(0,60)$, sehingga semua item untuk setiap variabel dalam penelitian ini dinyatakan reliabel dan dapat digunakan sebagai alat pengumpulan data. Perhitungan uji reliabilitas dalam penelitian ini menggunakan SPSS 21 dan hasil uji reliabilitas untuk masing-masing variabel dijelaskan dalam tabel 3. 


\section{ENTREPRENEUR}

Jurnal Bisnis Manajemen Dan Kewirausahaan

Program Studi Manajemen Fakultas Ekonomika dan Bisnis Universitas Majalengka

Published every June and December e-ISSN : (Proses), p-ISSN: 2723-1941

Available online https://ejournal.unma.ac.id/index.php/entrepreneur

Tabel 3. Hasil Uji Reliabilitas

\begin{tabular}{|c|c|c|c|c|}
\hline Varibel & $\begin{array}{c}\text { Total } \\
\text { ItemPertanyaan }\end{array}$ & $\begin{array}{c}\text { NilaiCronbach's } \\
\text { Alpha }\end{array}$ & $\begin{array}{c}\text { Nilai } \\
\text { Kritis }\end{array}$ & Keterangan \\
\hline Iklan & 5 & 0,840 & 0,60 & Reliabel \\
\hline Citra Merek & 5 & 0,800 & 0,60 & Reliabel \\
\hline KepuasanKonsumen & 7 & 0,880 & 0,60 & Reliabel \\
\hline
\end{tabular}

\section{Pengaruh Simultan}

\section{Pengujian Hipotesis}

\section{Pengaruh Pasrsial}

Pelaporan hasil pengujian hipotesis menunjukkan keberadaan pengaruh yang telah diduga dalam hipotesis. Tabel 4. menyajikan hasil analisis regresi untuk pengujian hipotesis pengaruh parsial variabel iklan dan citra merek terhadap kepuasan konsumen. Uji parsial menggunakan kriteria perbantingan antara $\mathrm{t}$ hitung dengan $t$ tabel $(1,984)$.

Tabel 4. Hasil Uji Parsial

\begin{tabular}{|l|c|c|}
\hline \multirow{2}{*}{} & \multicolumn{2}{|c|}{$\begin{array}{c}\text { Kepuasn } \\
\text { Konsumen }\end{array}$} \\
\cline { 2 - 3 } & $\mathrm{F}$ & sig. \\
\hline $\begin{array}{l}\text { Iklan dan Citra } \\
\text { Merek }\end{array}$ & 24,491 & 0,000 \\
\hline
\end{tabular}

Sumber: Data Diolah

Dari tabel 4 tersebut diketahui bahwa kedua variabel tersebut memiliki $\mathrm{t}$ hitung $>\mathrm{t}$ tabel dan nilai sig, < 5\%. Sehingga $\mathrm{H} 1$ dan $\mathrm{H} 2$ diterima. Artinya, terdapat pengaruh antara iklan terhadap kepuasan konsumen (H1) dan Terdapat pengaruh antara citra merekterhadap kepuasan konsumen $(\mathrm{H} 2)$.
Uji simultan dilakukan untuk menguji pengaruh iklan dan citra merek terhadap kepuasan konsumen. Pengujian ini yaitu dengan membandingkan $\mathrm{F}$ hitung dengan $\mathrm{F}$ tabel $(3,09)$ pada tingkat signifikansi $5 \%$. Berikut pelaporan hasil uji hipotesis simultan pada tabel 5 .

Tabel 5. Hasil Uji Parsial

\begin{tabular}{|l|c|c|c|}
\hline \multirow{2}{*}{ Iklan } & \multicolumn{3}{|c|}{ Kepuasn Konsumen } \\
\cline { 2 - 4 } & $\beta$ & $\mathrm{t}$ & sig. \\
\hline Citra Merek & 0,518 & 3,083 & 0,003 \\
& 1,101 & 6,257 & 0,000 \\
\hline
\end{tabular}

Sumber: Data Diolah

Tabel 5 tersebut menunjukkan bahwa F hitung $(24,491)>\mathrm{F}$ tabel $(3,09)$ dan nilai sig $<5 \%$. Artinya, terdapat oengaruh signifikan antara iklan dan citra merek terhadap kepuasan konsumen, sehingga $\mathrm{H} 3$ diterima.

\section{Pembahasan}

\section{Pengaruh Ilkan terhadap Kepuasan}

\section{Konsumen}

Hasil penelitian ini menunjukkan bahwa terdapat pengaruh yang signifikan antara iklan terhadap kepuasan konsumen. Iklan yang baik adalah iklan yang member pengaruh positif secara signifikan terhadap 


\section{ENTRREPRENEUR \\ Jurnal Bisnis Manajemen Dan Kewirausahaan \\ Program Studi Manajemen Fakultas Ekonomika dan Bisnis Universitas Majalengka \\ Published every January and July e-ISSN : (Proses), p-ISSN: 2723-1941 \\ Available online https://ejournal.unma.ac.id/index.php/entrepreneur}

minat konsumen, hal itu bias diwujudkan apabila promosi dilakukan secara intensif dan konsisten. Jika kepuasan konsumen meningkat, maka hasil penjualan pun akan meningkat. Sebaliknya, apabila promosi tidak dilakukan dengan intensif dan konsisten, maka minat konsumen pun akan berkurang atau pengaruh iklan terhadap minat konsumen tidak signifikan, hal itu dapat menyebabkan menurunnya hasil penjualan. Nilai skor tertinggi terdapat pada indikator disetiap produk iklan yang selalu menempel pada kemasannya. Artinya konsumen iklan dari produk tersebut karena iklan dari suatu produk sangat penting terutama bagi konsumen.

Hal ini selaras dengan hasil penelitian Illiatus Soleha, Rois arifin dan Afi Rahman S (2017). Mereka menyimpulkan persepsi iklan berpengaruh signifikan terhadap kepuasan konsumen. Dengan demikian semakin tinggi tingkat persepsi iklan pada dealer motor maka semakin tinggi pula kepuasan konsumen.

\section{Pengaruh Citra Merek terhadap Kepuasan Konsumen}

Dalam penelitian ini menunjukkan terdapat pengaruh signifikan antara citra merek terhadap kepuasan konsumen. Citra merek yang baik itu adalah memiliki kualitas atau mutu, berkaitan dengan kualitas produk barang yang ditawarkan oleh produsen dengan merek tertentu dipercaya atau diandalkannya berkaitan dengan pendapatan atau kesepakatan yang dibentuk oleh masyarakat tentang sesuatu produk yang dikonsumsi yaitu berupa pandangan, kesepakatan dan informasi yang berkaitan dengan suatu merek dari produk tertentu.
Adapun indikator dengan skor tertinggi yaitu pada indikator saya berharap Sepeda Motor Honda tetap menjaga citra produknya sebagai kendaraan yang aman. Artinya konsumen mengharapkan perusahaan selalu menjaga citra atau brand dari produk sepeda motor honda dengan mempertahankan keamanan dari setiap bahan produk.

Hasil penelitian ini mengkonfirmasi penelitian Illiatus Soleha, Rois arifin dan Afi Rahman S (2017). Mereka menyimpulkan persepsi iklan berpengaruh signifikan terhadap kepuasan konsumen. Jadi semakin tinggi tingkat persepsi iklan pada dealer motor maka semakin tinggi pula minat pembelian.

\section{Pengaruh Iklan dan Citra Merek Terhadap Kepuasan Konsumen}

Dalam penelitian ini menunjukkan bahwa terdapat pengaruh secara simultan antara iklan dan citra merek terhdap kepuasan konsumen. Kepuasan merupakan penilaian secara keseluruhan mengenai perusahaan, salah satunya dalah iklan dan citra merek. Konsumen yang puas ditandai dengan tingkat perhatian akan kualitas produk sangat bagus Kepuasan konsumen yang tinggi itu jika pelanggan puas, pasti akan terjadi sesuatu yang lebih baik untuk dimasa mendatang, konsumen akan menjadi loyal, pendapatan meningkat, kelangsungan bisnis terjamin, dan perusahaan jadi lebih unggul di tengah persaingan contohnya seperti kualitas produk dan kualitas pelayanan.

Dalam penelitian ini, iklan yang baik ditandai dengan indikator disetiap produk iklan yang selalu menempel pada kemasannya. Selain itu, responden merefleksikan bahwa sepeda motor honda 


\section{ENTREPRENEUR}

Jurnal Bisnis Manajemen Dan Kewirausahaan

Program Studi Manajemen Fakultas Ekonomika dan Bisnis Universitas Majalengka

Published every June and December e-ISSN : (Proses), p-ISSN: 2723-1941

Available online https://ejournal.unma.ac.id/index.php/entrepreneur

dapat menjaga citra merek dengan tetap memperhatikan keamanan serta kenyamanan untuk pengguna. Sehingga kedua aspek tersebut dapat membentuk suatu kepuasan kepada konsumen dalam pemakaian sepeda motor honda. Dengan demikian semakin baik iklan dan citra merek honda maka akan meningkatkan kepuasan konsumen.

\section{SIMPULAN dan IMPLIKASI Simpulan}

1. Iklan berpengaruh positif dan signifikan terhadap kepuasan konsumen. Artinya jika iklannya baik maka akan meningkatkan kepuasan konsumen begitu sebaliknya, jika iklannya kurang baik maka kepuasan konsumennya akan menurun.

2. Citra Merek berpengaruh positif dan signifikan terhadap kepuasan konsumen. Artinya semakin baik citra merek maka akan meningkatkan kepuasan konsumen begitupun sebaliknya, jika citra mereknya kurang baik maka kepuasan konsumennya akan menurun.

3. Iklan dan citra merek secara silmutan berpengaruh positif dan signifikan terhadap kepuasan konsumen. Artinya semakin baik iklan dan citra merek maka akan meningkatkan kepuasan konsumen.

\section{Implikasi Managerial}

Hasil peneiltian ini menjadi acuan bagi perusahaan dalam rangka pengambilan keputusan dari indikator-indikator mana yang dianggap lemah dapat dijadikan pedoman guna perbaikan di masa mendatang, khususnya yang menyangkut masalah kepuasan iklan, citra merek dan kepuasan konsumen sepeda motor honda.

\section{DAFTAR PUSTAKA}

Kotler, Philip dan Keller. (2007). Manajemen Pemasaran, Jilid I, Edisi Kedua belas, PT. Indeks, Jakarta

Tjiptono, Fandy. (2008). Strategi Pemasaran Edisi 3, ANDI : Yogyakarta

Fandy, Tjiptono. (2004). Manajemen Jasa, Edisi Pertama. Yogyakarta: Andi Offset.

Nugroho, J. Setiadi. (2007.) Perilaku Konsumen : Konsep dan Implikasi untuk Strategi dan Penelitian Pemasaran. Jakarta: Prenada Utama

Kotler, Philip and Keller, Kevin Lane. (2007). Manajemen Pemasaran. Edisi 12. Diterjemahkan oleh: Benyamin Molan. Jakarta: Indeks

Suhandang, Kustadi. (2005). Periklanan : Manajemen Kiat \& Strategi. Penerbit Nuansa. Bandung.

Uyung Sulaksana. (2007). Integrated Marketing Communications. Jakarta: Pustaka Pelajar

Tjiptono, Fandy. (2012). Strategi Pemasaran, ed. 3. Yogyakarta : Andi

Kotler, Philip \& Kevin Lane Keller. (2009). Manajemen Pemasaran, Edisi 13 jilid 1. Erlangga : Jakarta. 


\section{ENTREPRENEUR}

\section{Jurnal Bisnis Manajemen Dan Kewirausahaan}

\section{Program Studi Manajemen Fakultas Ekonomika dan Bisnis Universitas Majalengka}

Published every January and July e-ISSN : (Proses), p-ISSN: 2723-1941

Available online https://ejournal.unma.ac.id/index.php/entrepreneur

J. Supranto. (2006). Pengukuran Tingkat

Kepuasan Pelanggan : Untuk Menaikkan Pangsa Pasar. Jakarta : Rineka Cipta

Rangkuti, Freddy. (2004). The Power of Brand. Jakarta: PT. Gramedia Pustaka Utama.

Basu Swasta dan T. Hani Handoko. (2008). Manajemen Pemasaran, Analisa Perilaku Konsumen, edisi pertama, cetakan keempat. BPFE :Yogyakarta

Soleha, I., Arifin, R., \& Slamet, A. R. (2017). Pengaruh Citra Merek Dan Persepsi Label Halal Terhadap Minat Pembelian Ulang Produk Kosmetik Zoya Malang. Jurnal Ilmiah Riset Manajemen, 6(02). 